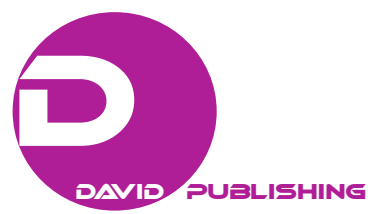

\title{
Addressing Religious Issues at UAE Schools in Times of Global Changes
}

\author{
Ameera Ahmed Almessabi \\ United Arab Emirates University, Al Ain, UAE
}

\begin{abstract}
After the era of globalization, religious diversity increases in most of the countries all over the world. Therefore, the main goal of this article is to discuss the necessity of teaching pupils about the different religions at schools in order for increasing their religious awareness about their own religion as well as improving their sensitivity towards other religions. Hence, such awareness and sensitivity may contribute to open the channels of dialogue among the new generations and prevent more violence from happening, as a result. In doing so, it will display the level of religious diversity around the world and the number of expected religious groups by 2050 as found by Pew Research Center (2015). It will also briefly review the Islamic principles that are related to dealing with other religious groups. Moreover, it will present possible ways of how multiple religions can be taught in schools in order to transform pupils from religiocentric phases to religiorelative stages.
\end{abstract}

Keywords: UAE schools, postmodern era, globalization, diversity, religions, extremist groups, Islamic principles, tolerance

\section{Introduction}

Living in the postmodern era which is characterized by a fast-changing concept of time is so confusing and unpredictable. The whole world becomes one small village and its people share many similar aspects of life and are affected by shared problems. To illustrate, globalization's spoon mixes the different races, ethnicities, cultures, languages, socioeconomics, and religions in each single country. All of these elements of diversity should be handled wisely to avoid conflicts and contradictions among humans. This paper deals with religious diversity to address religious issues in UAE schools and the necessity for teaching students about the major religions in order to prepare this generation with religious awareness that makes them learn better about their own religion and at the same time respect other religions. Consequently, such awareness will open the window for dialogue among the new generations and as a result may contribute to save the world from the current wars and violence which stem initially from religious extremism. This position paper is undertaken to provide a critical discussion of key aspects of the definition and interpretation of religion and religious diversity. A presentation of justifications for why and how diverse religions should be taught in UAE schools is also presented. A brief discussion of Islamic principles that relate to religious diversity and tolerance is discussed as well.

Ameera Ahmed Almessabi, PhD candidate, Researcher, Foundations of Education, United Arab Emirates University. 


\section{Religion and Religious Diversity}

There are many definitions for the word religion and some of them are general and can be implemented to all religions, while the other are so unique to specified religions. For instance Geertz (1993) in his book religion as a cultural system, he defines religion as cultural system of practices, sacred texts, common views, morals, ethics, holy places, behaviors, and a rational to humans for their existence. Similarly, Yinger (1970) argues that religion is a set of practices and beliefs of a group of people that derive their behaviors. James (1902), in his book the varies of religious experience, defines religion as "the feelings, acts, and experiences of individual men in their solitude, so far as they apprehend themselves to stand in relation to whatever they may consider the divine" (p. 31). on the other hand, Durkheim (1969) defines religion in a specific way as (Christianity) as "a unified system of beliefs and practices relative to sacred things, that is to say, things set apart and forbidden beliefs and practices which unite into one single moral community called a church (sic), all those who adhere to them" (p. 46). Generally speaking, most definitions of religions agreed on the concept of deity, norms, sacred beliefs that shape the human behaviors and practices. In other words, religious beliefs and principles determine and shape the culture of a group of people including their way of eating, clothing, getting married and so forth. After the era of globalization, religious diversity increases in most of the countries all over the world. However we are here in UAE do not have many religions as other countries might have, for example, USA and European countries. The great majority here in UAE are Muslims, however, because of globalization, the whole world might witness dynamic changes in religions' diffusion during the coming years (see Figures 1 and 2).

Therefore, all countries including UAE need to prepare its generations for being aware about these religions in order to strengthen their faith about their own religion as well as increase their respect towards the other religions. As a result, that will open the communication channels among people from different religions and, in consequence, will decrease the number of wars all over the world. That can be reached when countries are able to raise the level of interreligious sensitivity among its citizens. Following the same categories as Bennett (1993) used in his developmental model of intercultural sensitivity, Morgan and Sandage (2016) created their Interreligious Competence model IRC (see Table 1). Likewise, Abu-Nimer (2001) proposes that denial is represented by religious tenets that negate the humanity of those outside the creed. While defense, in his model, is interpreted as the belief of an individual who values his/her own religion and at the same time devalues all the others. Finally, he describes the religiocentric perspective of minimization as when individuals "begins from their own beliefs and see the same beliefs among others" (p. 500). Moreover, Abu-Nimer (2001) describes the shift from religiocentric to religiorelative view as an arduous task: "participants in the training workshops, regardless of their faith, had difficulty applying the developmental model in the religiorelative stages when religion was substituted for culture" (p. 699). He repeats discussing this enigma in Abu-Nimer (2004) when he states that "possibility of developing a religious pluralist consciousness is rejected by most of the interfaith dialogue groups, because it raises the fear of conversation and the loss of one's perceived authentic religious identity" (p. 503). Therefore, he suggests that acceptance might be the highest point of growth for religious people because any further stage might be interpreted as bargaining their own faith. Although, the acceptance stage can be so helpful in opening the window among the different religions, our role as parents and educators is to help our children to reach it and move beyond to the adaptation and integration stages. 


\section{Projected Change in Global Population}

With the exception of Buddhists, all of the major religious groups are expected to increase in number by 2050 . But some will not keep pace with global population growth, and, as a result, are expected to make up a smaller percentage of the world's population in 2050 than they did in 2010.

Number of people, 2010-2050, in billions

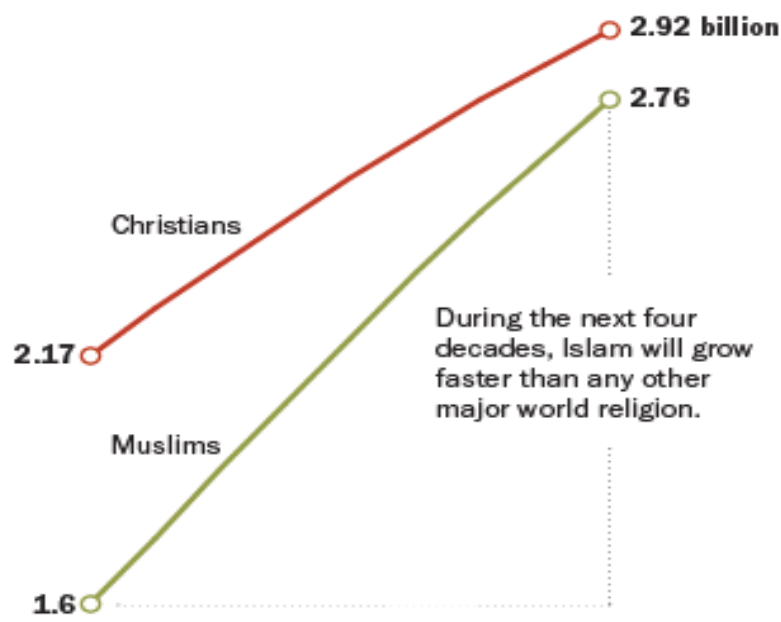

138

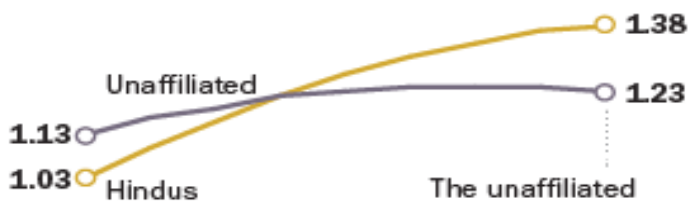

population will increase by nearly $10 \%$ in the decades ahead. But ...
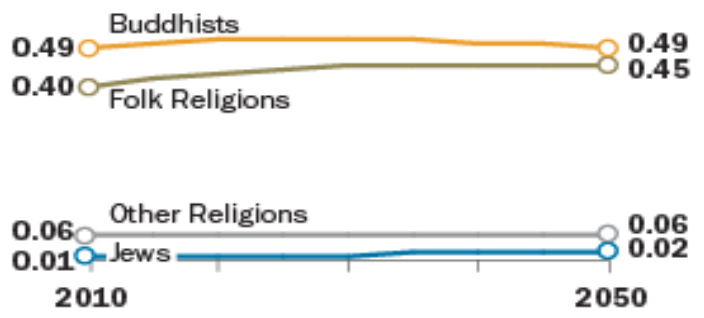

$\%$ of global population, 2010-2050
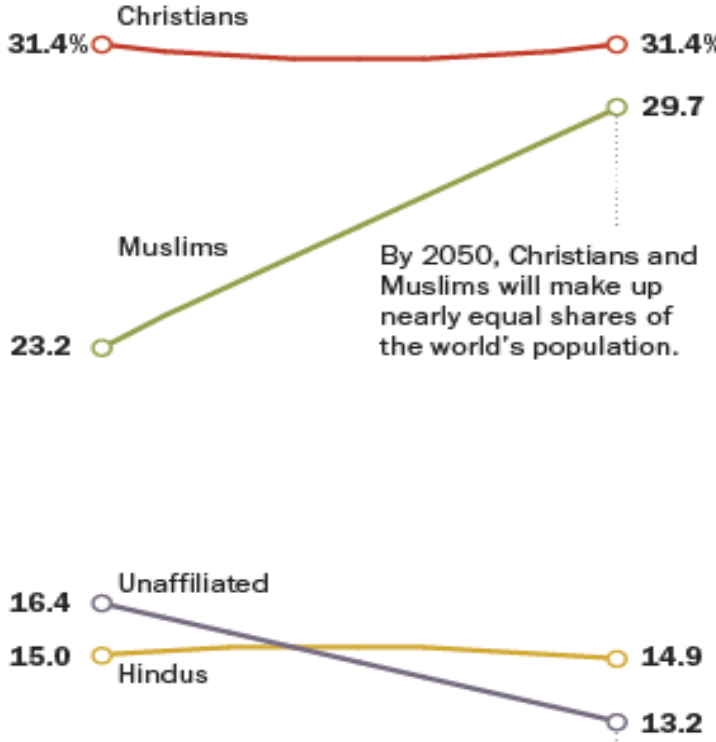

... from 2010 to 2050 , the religiously unaffiliated will decline as a share of the global population.
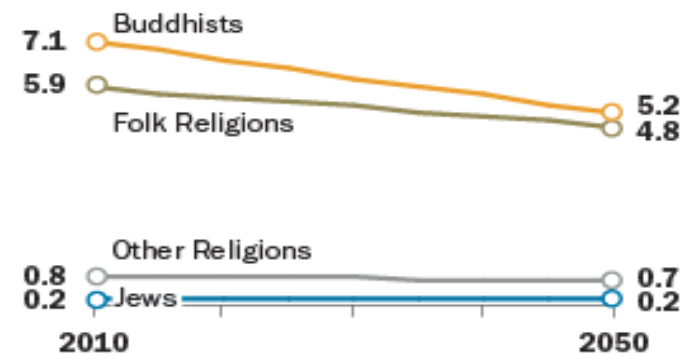

Source: The Future of World Religjons: Population Growth Projections, 2010-2050

PEW RESEARCH CENTER

Figure 1. Projected change in global population (Number of excepted religious groups by 2050) (Pew Research Center, 2015). 


\section{Size and Projected Growth of Major Religious Groups}

\begin{tabular}{lcccccc} 
& 2010 POPULATION & $\begin{array}{c}\text { \% OF WORLD } \\
\text { POPULATION } \\
\text { IN 2010 }\end{array}$ & $\begin{array}{c}\text { PROJECTED 2050 } \\
\text { POPULATION }\end{array}$ & $\begin{array}{c}\text { \% OF WORLD } \\
\text { POPULATION } \\
\text { IN 2050 }\end{array}$ & $\begin{array}{c}\text { POPULATION } \\
\text { GROWTH 2010 } \\
\text { 2050 }\end{array}$ \\
Christians & $2,168,330,000$ & $31.4 \%$ & $2,918,070,000$ & $31.4 \%$ & $749,740,000$ \\
\hline Muslims & $1,599,700,000$ & 23.2 & $2,761,480,000$ & 29.7 & $1,161,780,000$ \\
\hline Unaffiliated & $1,131,150,000$ & 16.4 & $1,230,340,000$ & 13.2 & $99,190,000$ \\
\hline Hindus & $1,032,210,000$ & 15.0 & $1,384,360,000$ & 14.9 & $352,140,000$ \\
\hline Buddhists & $487,760,000$ & 7.1 & $486,270,000$ & 5.2 & $-1,490,000$ \\
\hline Folk Religions & $404,690,000$ & 5.9 & $449,140,000$ & 4.8 & $44,450,000$ \\
\hline Other Religions & $58,150,000$ & 0.8 & $61,450,000$ & 0.7 & $3,300,000$ \\
\hline Jews & $13,860,000$ & 0.2 & $16,090,000$ & 0.2 & $2,230,000$ \\
\hline World total & $\mathbf{6 , 8 9 5 , 8 5 0 , 0 0 0}$ & $\mathbf{1 0 0 . 0}$ & $\mathbf{9 , 3 0 7 , 1 9 0 , 0 0 0}$ & $\mathbf{1 0 0 . 0}$ & $\mathbf{2 , 4 1 1 , 3 4 0 , 0 0 0}$
\end{tabular}

Source: The Future of World Religions: Population Growth Projections, 2010-2050

PEW RESEARCH CENTER

Figure 2. Size and projected growth of major religious groups (Pew Research Center, 2015).

Table 1

Summary of Developmental Model of IRC by Morgan and Sandage (2016, p. 143)

\begin{tabular}{|l|l|}
\hline Denial & $\begin{array}{l}\text { This orientation has difficulty acknowledging religious differences beneath those that are apparent, and acts } \\
\text { with a general avoidance or dismissal of religious others }\end{array}$ \\
\hline Polarization & $\begin{array}{l}\text { Orientations that construe religious differences through rigid either/or categories based on } \\
\text { superiority/inferiority }\end{array}$ \\
\hline Defense & $\begin{array}{l}\text { An orientation that idealizes one's own religious position with in-group loyalty and denigrates religious others } \\
\text { through stereotyped prejudices and often with a sense of being threatened by out-groups }\end{array}$ \\
\hline Reversal & $\begin{array}{l}\text { The inverse of defense, this mindset adopts a globally critical view of one's own religious tradition, often with } \\
\text { shame, and idealizes religious others }\end{array}$ \\
\hline Minimization & $\begin{array}{l}\text { This orientation subsumes other's categories into familiar religious ideas (e.g., "All religions are saying the } \\
\text { same thing"). This emphasis on similarity often obscures recognition of important religious differences }\end{array}$ \\
\hline Acceptance & $\begin{array}{l}\text { Through increased cognitive complexity and emotional Flexibility, this orientation permits frame-shifting to } \\
\text { recognize and appreciate religious differences while remaining self-aware of one's own religious preferences } \\
\text { and perspectives. }\end{array}$ \\
\hline Adaptation & $\begin{array}{l}\text { Beyond the frame-shifting of acceptance, this orientation also includes the capacity to behaviorally } \\
\text { code-switch, i.e., act in respectful and appropriate ways across religious differences. }\end{array}$ \\
\hline Integration & $\begin{array}{l}\text { An orientation that involves "living out" adaptation and commitments to inter-religious relationships in healthy } \\
\text { ways amidst the stress and marginality that if often comes with those commitments. }\end{array}$ \\
\hline
\end{tabular}

\section{Religious Diversity in UAE's Community}

After the bull market in UAE because of discovering the oil, the components of UAE community has been changed to contain other nationalities. To illustrate, $20 \%$ of the UAE's population are Emiratis (Ministry of Economy Consensus, 2005). While, the rest of them are non-nationals with $80 \%$ came to UAE for seeking of employments' opportunities (see Table 2). According to the most recent Ministry of Economy census of United Arab Emirates (2005), 76 percent of the total population is Muslim, 9 percent is Christian, and 15 percent is "other", including Hindu and Buddhist. 
Table 2

Percentages of People From Other Nationalities Live in UAE

\begin{tabular}{|l|l|}
\hline Other Arabs (e.g., Yemenis, Jordanians, Egyptians, Syrians, Iraqis,...). & $23 \%$ \\
\hline East and South East Asian (e.g., Indians, Pakistanis,...) & $50 \%$ \\
\hline Other expatriates (Westerners) & $7 \%$ \\
\hline
\end{tabular}

\section{Islamic Principles Related to Other Religions}

Here in UAE, the official religion is Islam. Yahya (2000) argues that Islam has the highest degree of tolerance in permitting other people of other beliefs to practice their religious values, regardless of the high level of contradictions between these faiths and Islam. Islam urge Muslims to view the case of others sympathetically, respectively, and justly. That can be manifest in this verse from holy Quran "God forbids you not, with regard to those who fight you not for your faith, nor drive you out of your homes, from dealing kindly and justly with them, for God loves those who are just" (Al-Mumtahnah: 8). Moreover, Allah also says: "The truth is from your Lord, so whoever wills-let him believe; and whoever wills—-let him disbelieve" (Al-Kahf: 29). Therefore, Muslims are asked to respect other religions, whether these religions are in agreement or disagreement with their beliefs.

Tolerance helps humans to live together in harmony and that is highly needed during globalization which is characterized by different mixes of cultures and religions. Accordingly, living in peace requires from us as humans to respect all of these differences, instead of covering our eyes and avoid tackling these sensitive issues. Frankly speaking, such avoidance is the main reason behinds wars and conflicts which are currently happening all over the world. Extremist groups are formed from the lack of understanding of other religions and then people believe that there religion is the only right faith in the world. Allah says "God knows best what you are doing; God will judge between you on the Day of Judgment concerning the matters in which you differ" (AI-Hajj: 68-69). However, unfortunately, extremists may go beyond this belief and they initiate some extreme illegal groups which destruct countries and fight mistakenly in the name of religion. The worst is that these extreme groups utilize the new technology in the postmodernity in inviting other people to adopt their ideas and faiths in order to make them their soldiers. In consequence, we suffer as humans from wars and their negative consequences in many countries in the world. We as Muslims should represent that tolerance by addressing the issues of religious diversity among us. Basically, it is a shared responsibility among homes, schools, and media to save the world and stop these wars which are practiced in the name of religion. The following paragraph discusses the role of school to do so.

\section{Curriculum and Pedagogical Issues Related to Teaching about Religions}

There are many scholars and intellectuals argue for involving religious discussions and teaching about religions in schools to enrich the students' knowledge about these different religions by presenting them in full neutrality (Uphoff, 1993; Haynes \& Thomas, 2001; Cushner, McClelland, \& Stafford, 2011; Slattery, 2013). This neutrality is for fostering discussion and inquiry with avoiding evangelism. Educators can do so through multiple ways to present the diverse beliefs and the most effective one is to include religious issues in the curriculum (Whittaker, Salend, \& Elhoweris, 2009). Moreover, In a book called Religion in the Public Schools (1964), the American Association of School Administrators argues that religious issues cannot be avoided in designing curriculum because it is an integral part of an individual's culture which must be included (cited in 
Uphoff, 1993, p. 95). According to Cushner, McClelland, and Stafford (2011) it is worthwhile to study at schools about the various religions and their influences on the world civilization.

Generally speaking, teaching about religions can take a form of a separate subject matter that specified in presenting neutrally the main principles for each religion of the five worldwide religions: Islam, Christianity, Judaism, Buddhism, and Hindu. Moreover, religious issues can also be included in other subject matters such as history, social studies, math, geography, art, and so forth, in order to either present the influence of religions on particular elements of these subjects or use examples from religions to facilitate teaching these subjects (Douglass, 2002; Haynes, 2005; Whittaker, Salend, \& Elhoweris, 2009; Cushner, McClelland, \& Stafford, 2011). For example, a math teacher can use different types of architecture of houses of worship in teaching geometry (Whittaker, Salend, Elhoweris, 2009; Cushner, McClelland, \& Stafford, 2011). It is worth mentioning that curriculum materials and resources should be closely supervised to avoid extreme bias, however, with maintaining a level of bias for the aim of asking students to critically analyze the texts and figure out the types of bias and prejudice towards different religions in order for reducing some stereotypes and myths about those religions (Cushner, McClelland, \& Stafford, 2011; Slattery, 2013). This criticizing and analyzing for different literature of multiple religions foster knowledge construction and critical thinking (Banks, 1988). In other words, critical analysis for these religious stories and texts will liberate the students' minds and, as a result, it will help societies to prepare a generation of independent and autonomous citizens (Greene, 1974; Freire, 1984).

\section{Conclusion}

As a successful country, we have to be aware that we live in an open world. Therefore, most of the world's countries have similar aims, interests, fears and may be destinies. It is undoubtable that the whole world becomes one place that has a mix of different races, ethnicities, languages, values, norms, social classes, genders, cultures, and religions. Typically, all countries all over the world search for ways to prepare their generations for successful participation in a global economy and at the same time to maintain their own cultural identity. Living in peace demands us as humans to address these issues of diversity and deal with them so sensitively and wisely. Unfortunately, today we witness destructions and wars in many countries in the name of religion. Researchers predict that future may witness more level of diversity and that can be a real challenge for us to deal with. Therefore, to avoid more conflicts and aggressions, we need to appreciate all types of diversity and open discussions among the new generations to learn about their own faith and at the same time be informed about the other religions. As a consequence, these students will strengthen their faith as well as be immune and indomitable from the extremists who use new technology in postmodern era for spreading their extreme beliefs and establishing destructive groups to destroy the world.

\section{References}

“The Future of World Religions: Population Growth Projections, 2010-2050”. (2015). Pew Research Center, Washington, D. C. Retrieved from http://www.pewforum.org/2015/04/02/religious-projections-2010-2050/pf_15-04-02_projectionstables8/

Abu-Nimer, M. (2001). Conflict resolution, culture, and religion: Toward a training model of interreligious peace building. Journal of Peace Research, 38(6), 685-704.

Abu-Nimer, M. (2004). Religion, dialogue, and non-violent actions in Palestinian-Israeli conflict. International Journal of Politics, Culture, and Society, 17(3), 491-511.

Banks, J. A. (1988). Multiethnic education: Theory and practice (2nd ed.). Boston: Allyn \& Bacon. 
Bennett, M. J. (1993). Towards ethnorelativism: A developmental model of intercultural sensitivity. In M. Paige (Ed.), Cross-cultural orientation (pp. 27-69). Lanham, MD: University Press of America.

Cushner, K., McClelland, A., \& Stafford, P. (2011). Human diversity in education: An intercultural approach (7th ed.). Boston: McGraw Hill.

Douglass, S. L. (2002). Teaching about religion. Educational Leadership, 60(2), 32-37.

Durkheim, E. (1969). The social foundations of religion. In R. Robertson (Ed.), Sociology of religion. Baltimore: Penguin Books.

Freire, P. (1984). Education, liberation, and the church. Religious Education, 79, 524-45.

Geertz, C. (1993). Religion as a cultural system. In G. Clifford (Ed.), The interpretation of cultures: Selected essays (pp. 87-125). Fontana Press.

Green, C., \& Oldendorf, S. (2005). Teaching religious diversity through children's literature. Childhood Education, 8(4), $209-218$.

Greene, M. (1974). Literature, existentialism, and education. In D. E. Denton (Ed.), Existentialism and phenomenology in education (p. 75). New York: Teachers College Press.

Haynes, C. C. (2005). Living with our deepest differences: Religious diversity in the classroom. In D. A. Byrnes \& G. Kiger (Eds.), Common bonds: Anti-bias teaching in a diverse society (pp. 25-35). Olney, MD: Association of Childhood Education International.

Haynes, C. C., \& Thomas, O. (2001). Finding common ground: A guide to religious liberty in public schools. Nashville, TN: First Amendment Center.

James, W. (1902). The varieties of religious experience: A study in human nature. New York, London: Longmans, Green, and Co. Morgan, J., \& Sandage, S. J. (2016). A developmental model of interreligious competence: A conceptual framework. Archive for the Psychology of Religion, 38, 129-158.

Preliminary Results of Population, Housing and Establishments Census. (2005). Ministry of Economy. United Arab Emirates.

Slattery, P. (2006). Curriculum development in the postmodern era (2nd ed.). New York, NY: Taylor \& Fransis Group.

Slattery, P. (2013). Curriculum development in the postmodern era: Teaching and learning in an age of accountability (3rd ed.). New York: Routledge/Taylor \& Francis.

Uphoff, J. K. (1993). Religious diversity and education. In J. A. Banks, \& C. A. McG Banks (Eds.), Multicultural education: Issues and perspectives (2nd ed.). Boston: Allyn \& Bacon.

Whittaker, C., Salend, S. J., \& Elhoweris, H. (2009). Religious diversity in schools: Addressing the issues. Intervention in School and Clinic, 44(5), 314-319.

Yahya, H. (2000). The basic concepts in the Quran. New Delhi, India: Goodword Press.

Yinger, J. M. (1970). The scientific study of religion. New York: Macmillan. 